INDEPENDENT JOURNAL OF MANAGEMENT \& PRODUCTION (IJM\&P)

http://www.ijmp.jor.br

v. 11, n. 1, January-February 2020

ISSN: 2236-269X

DOI: 10.14807/ijmp.v11i1.1010

\title{
NETWORK COOPERATIVES AND THE REDUCTION OF OPPORTUNISM IN THE AGRIBUSINESS SEGMENT: A SYSTEMATIC BIBLIOGRAPHIC REVIEW
}

\author{
Leandro Guedes Aguiar \\ Universidade Estadual Paulista "Júlio de Mesquita Filho", Brazil \\ E-mail: lelaaguiar@hotmail.com \\ Giuliana Santini Pigatto \\ Universidade Estadual Paulista "Júlio de Mesquita Filho", Brazil \\ E-mail: giuliana.santini@unesp.br \\ Cristiane Hengler Bernardo \\ Universidade Estadual Paulista "Júlio de Mesquita Filho", Brazil \\ E-mail: cristiane.bernardo@unesp.br \\ Angélica Gois Morales \\ Universidade Estadual Paulista "Júlio de Mesquita Filho", Brazil \\ E-mail: ag.morales@unesp.br \\ Submission: 2/27/2019 \\ Revision: 3/19/2019 \\ Accept: 4/10/2019
}

\section{ABSTRACT}

The Brazilian citrus industry has been the focus of in-depth scientific research in the 21st century, mainly due to the peculiarities of the coordination of this agroindustrial system, in which the cooperatives' performance and network format are highlighted. This represents an alternative to the well-known process of reduction of small citrus producers, as well as support in mitigating opportunism in transactions. In this context, the objective of this article is to carry out a systematic review of the literature on the topic of cooperatives that use a network format and the reduction of opportunism applied to the agribusiness segment in Brazil and worldwide. As a result, the importance of networked agro-industrial cooperatives to reducing opportunism in economic transactions is attested in all the researched articles, as is the lack of empirical academic studies to enrich and make the researched literature more robust.

Keywords: governance; network; systematic review of the literature; citriculture; cooperative. 
ISSN: $2236-269 X$

DOI: $10.14807 /$ ijmp.v11i1.1010

\section{INTRODUCTION}

The Brazilian citrus industry has been the focus of in-depth scientific research in the twenty-first century, mainly due to the peculiarities that exist in the coordination of this agroindustrial system, in which increasing verticalization by the processing industry is highlighted by the concentration of production on larger properties and the reduction of the participation of small producers, both in terms of properties and productivity, making cooperatives a way to remain active in the system when faced with the difficulties of the market (PAULILLO et al., 2010; FUNDECITRUS, 2017).

Neves et al. (2010) highlight the efficiency of associations, cooperatives and other networking models that integrate citrus producers to contend with the current market concentration scenario. In the same line, Kalaki (2014) highlights the need to encourage associativism and cooperativism in agribusiness, especially among small producers, seeking to encourage this group to demonstrate greater representativeness and competitiveness.

Granovetter (2007) identifies the integral role of concrete personal relationships in networked structures as trust-promoting agents and inhibitors of bad faith, whereby preference is shown by carrying out transactions with individuals of known reputation. In this way, the author highlights social network relationships and their role in the promotion of order and stability, in which attributes such as trust, reputation and identification among agents are the primary social elements that reduce opportunism.

In that sense, attaining an understanding the state of existing research about networked agribusiness cooperatives and the ways such organizations can reduce opportunism becomes important. Observing the advances in the discussions and identifying research gaps provides opportunities for future research. To carry out a bibliographic review with greater rigor and reliability, the systematic bibliographic review (SBR) method proposed by Levy and Ellis (2006) and Conforto, Amaral and Silva (2011) was chosen for this article.

According to Conforto, Amaral and Silva (2011), one way to obtain greater rigor and higher reliability in a bibliographic review is to adopt a systematic approach that includes the definition of a strategy and a systemic method for research and analysis of results. In this sense, SBR is a useful instrument for mapping published works in a specific research area to enable researchers to elaborate on and synthesize existing knowledge about the subject (BIOLCHINI et al., 2007). 
DOI: 10.14807/ijmp.v11i1.1010

In this context, the objective of this article is to perform a systematic review of the literature on networked cooperatives and the reduction of opportunism in the agribusiness sector in Brazil and worldwide. This article contributes to the research on and discussion of networked cooperatives and opportunism in agribusiness, taking into account the characteristics of this sector on a global scale and the large number of actors that differ in terms of size and access to information.

The article begins with a discussion of the approach and research method used, followed by the presentation of results and discussions, providing a general and bibliometric overview of the reviewed publications, as well as the constructed concepts and content presented. Then, final considerations are presented to conclusively synthesize the main contributions regarding the content under analysis, as well as its theoretical contribution so far.

\section{RESEARCH METHOD}

The main method used in this study is the SBR model presented by Levy and Ellis (2006) and Conforto, Amaral and Silva (2011). SBR is characterized by three main phases: input, processing and output. These can be observed in the model used and the SBR roadmap presented in Frame 1.

Frame 1: Systematic bibliographic review conducting model - SBR Roadmap

\begin{tabular}{|l|l|l|}
\hline \multicolumn{1}{|c|}{ 1. Input } & \multicolumn{1}{|c|}{ 2. Processing } & \multicolumn{1}{c|}{ 3. Output } \\
\hline 1.1. Problem & 2.1. Search & 3.1. Register and archive \\
1.2. Objectives & 2.2. Reading, analysis and selection & 3.2. Synthesis and results \\
1.3. Sources & 2.3. Documentation & \\
1.4. Search strings & & \\
1.5. Inclusion criteria & & \\
1.6. Qualifying criteria & & \\
1.7. Methods and tools & & \\
\hline
\end{tabular}

Source: Adapted from Conforto, Amaral and Silva (2011).

According to Conforto, Amaral and Silva (2011), during the input phase, it is important to define the research problem and objectives, main sources and keywords to be searched, criteria for inclusion of articles and methods and tools to be used. It is also important to create an input protocol containing all this information in an organized way.

The search for publications using the guidelines defined will be executed in the processing phase along with the reading, analysis, selection and documentation of the material. This will be followed by the output phase, in which the selected materials will be registered 
ISSN: 2236-269X

DOI: 10.14807/ijmp.v11i1.1010

and archived to further synthesize the results obtained from the bibliographic review (CONFORTO; AMARAL; SILVA, 2011).

The presentation and structuring of the SBR will be discussed in the following subtopics in light of the SBR Roadmap model and the theme of this article.

\subsection{Input}

As already discussed, the input phase is characterized by the preparation of the input protocol, which contains essential information for the execution and continuation of the SBR, as presented in Figure 1.

\begin{tabular}{|c|c|}
\hline Problem & $\begin{array}{l}\text { What are the publications on the topic of cooperatives that use a network format and the } \\
\text { reduction of opportunism applied to the agribusiness segment? }\end{array}$ \\
\hline Objective & $\begin{array}{l}\text { Execute a systematic review of the literature on the topic of cooperatives that use a } \\
\text { network format and the reduction of opportunism applied to the agribusiness segment in } \\
\text { Brazil and worldwide. }\end{array}$ \\
\hline Sources & JSTOR, Portal Periódicos Capes, Scielo, Science Direct, Scopus and Web of Science \\
\hline $\begin{array}{l}\text { Search } \\
\text { Strings }\end{array}$ & $\begin{array}{c}\text { ("cooperativa" AND "rede" AND "oportunismo" AND "agronegócio") OR ("cooperative" AND } \\
\text { "network" AND "opportunism" AND "agribusiness") }\end{array}$ \\
\hline $\begin{array}{l}\text { Inclusion } \\
\text { Criteria }\end{array}$ & $\begin{array}{l}\text { Only literature dealing with topics related to cooperatives that use a network format and the } \\
\text { problem of opportunism in agribusiness. }\end{array}$ \\
\hline $\begin{array}{l}\text { Methods and } \\
\text { tools }\end{array}$ & Software StArt and Microsoft Office Excel, if necessary. \\
\hline
\end{tabular}

Figure 1: SBR Input protocol

Source: Prepared by the authors.

Considering the definition and alignment of the problem, objective, main sources and the strings to be used in the research, we opted to use the StArt (State of Art through Systematic Review) software to conduct the SBR. In general, the processing phase is conducted using data from the input phase to obtain a higher index of management and registration for all data obtained. This is achieved using the defined steps and facilitates greater robustness and transparency in the final data analysis.

\subsection{Processing}

The processing phase was performed by entering the search strings on the six databases selected for research, as defined in the input protocol, and applying filters to these same databases. We also filtered the articles by first reading their titles, abstracts and keywords. We then read the introductions and conclusions of the material obtained using Filter 1. The search 
INDEPENDENT JOURNAL OF MANAGEMENT \& PRODUCTION (IJM\&P)

http://www.ijmp.jor.br

v. 11, n. 1, January-February 2020

ISSN: 2236-269X

DOI: 10.14807/ijmp.v11i1.1010

results, along with the application of the filters to the processing phase, is presented in Frame 2.

Frame 2: Results of the searches and filters used in the selection of the bibliography of interest

\begin{tabular}{|c|c|c|c|c|c|c|}
\hline Database & JSTOR & $\begin{array}{l}\text { Portal } \\
\text { Periódicos } \\
\text { Capes }\end{array}$ & Scielo & Science Direct & Scopus & $\begin{array}{l}\text { Web of } \\
\text { Science }\end{array}$ \\
\hline Date of collection & 17thAug, 2018 & 17thAug, 2018 & 17thAug, 2018 & 17thAug, 2018 & 17thAug, 2018 & 17thAug, 2018 \\
\hline Boolean search & \multicolumn{6}{|c|}{$\begin{array}{l}\text { ("cooperativa" AND "rede" AND "oportunismo" AND "agronegócio") OR ("cooperative" AND "network" } \\
\text { AND "opportunism" AND "agribusiness") }\end{array}$} \\
\hline $\begin{array}{l}\text { Result: Boolean } \\
\text { search }\end{array}$ & 24 documents & 110 documents & 2 documents & 36 documents & 0 documents & 0 documents \\
\hline Filter 1 & \begin{tabular}{|c|} 
Areas: \\
Business; \\
Econ.; Manag. \& \\
Org. Behavior; \\
Political Science; \\
Public Policy \&. \\
Administration
\end{tabular} & $\begin{array}{l}\text { There was no } \\
\text { such stage }\end{array}$ & $\begin{array}{l}\text { There was no } \\
\text { such stage }\end{array}$ & $\begin{array}{l}\text { There was no } \\
\text { such stage }\end{array}$ & $\begin{array}{l}\text { There was no } \\
\text { such stage }\end{array}$ & $\begin{array}{l}\text { There was no } \\
\text { such stage }\end{array}$ \\
\hline Result: Filter 1 & 21 documents & 110 documents & 2 documents & 36 documents & 0 documents & 0 documents \\
\hline Filter 2 & $\begin{array}{l}\text { Language: } \\
\text { English and } \\
\text { Portuguese }\end{array}$ & $\begin{array}{l}\text { Language: } \\
\text { English and } \\
\text { Portuguese }\end{array}$ & $\begin{array}{l}\text { Language: } \\
\text { English and } \\
\text { Portuguese }\end{array}$ & $\begin{array}{l}\text { Language: } \\
\text { English and } \\
\text { Portuguese }\end{array}$ & $\begin{array}{l}\text { There was no } \\
\text { such stage }\end{array}$ & $\begin{array}{l}\text { There was no } \\
\text { such stage }\end{array}$ \\
\hline Result: Filter 2 & 21 documents & 98 documents & 2 documents & 36 documents & 0 documents & 0 documents \\
\hline Filter 3 & $\begin{array}{c}\text { Reading: Title, } \\
\text { abstract and } \\
\text { keyword }\end{array}$ & $\begin{array}{c}\text { Reading: Title, } \\
\text { abstract and } \\
\text { keyword }\end{array}$ & $\begin{array}{c}\text { Reading: Title, } \\
\text { abstract and } \\
\text { keyword }\end{array}$ & $\begin{array}{c}\text { Reading: Title, } \\
\text { abstract and } \\
\text { keyword }\end{array}$ & $\begin{array}{l}\text { There was no } \\
\text { such stage }\end{array}$ & $\begin{array}{c}\text { There was no } \\
\text { such stage }\end{array}$ \\
\hline Result: Filter 3 & 1 document & 18 documents & 0 documents & 4 documents & 0 documents & 0 documents \\
\hline Filter 4 & $\begin{array}{c}\text { Reading: } \\
\text { Introduction and } \\
\text { conclusion } \\
\end{array}$ & $\begin{array}{c}\text { Reading: } \\
\text { Introduction and } \\
\text { conclusion } \\
\end{array}$ & $\begin{array}{c}\text { Reading: } \\
\text { Introduction and } \\
\text { conclusion }\end{array}$ & $\begin{array}{c}\text { Reading: } \\
\text { Introduction and } \\
\text { conclusion } \\
\end{array}$ & $\begin{array}{l}\text { There was no } \\
\text { such stage }\end{array}$ & $\begin{array}{c}\text { There was no } \\
\text { such stage }\end{array}$ \\
\hline Result: Filter 4 & 0 documents & 5 documents & 0 documents & 0 documents & 0 documents & 0 documents \\
\hline
\end{tabular}

Source: Prepared by the authors.

As shown in Frame 2, the processing phase included 172 documents in its initial stage. After the application of Filters 1 and 2 (related to areas of interest and languages, respectively), this number was reduced to 157 documents, which were considered for the composition of information in the StArt tool, allowing the optimization and application of Filter 3 (reading the titles, abstracts and keywords). We obtained a result of 118 rejected documents, 16 duplicate documents and 23 accepted documents.

The final stage of the processing phase involved the application of Filter 5 (reading of the introductions and conclusions) to the 23 accepted documents. These were submitted to inclusion and exclusion criteria, taking into account, for example, the relationship between the documents and the themes of new institutional economy, agro-industrial cooperatives, network 
ISSN: 2236-269X

DOI: 10.14807/ijmp.v11i1.1010

theory and opportunism, as well as the interrelation between the topics. As a result, five articles were selected for complete reading, which determined the acceptance and continuity of all articles for the composition of this bibliographic review, as well as their participation in the output phase.

\subsection{Output}

As noted previously, the third and final stage of the SBR comprises the output phase, in which the selected documents are cataloged and archived, making it possible to analyze the publications' content and bibliometric data.

Frame 3 presents the basic information about the five articles selected for this bibliographic review, including title, authors, publishing journal and year of publication.

Frame 3: Key information about the selected final articles

\begin{tabular}{|c|c|c|c|c|}
\hline $\mathbf{N}^{0}$ & Title & Authors & Journal & Year \\
\hline 1 & $\begin{array}{l}\text { The role of social capital in the } \\
\text { industrialization of the food system }\end{array}$ & $\begin{array}{l}\text { Robinson, L. J.; Schmid, } \\
\text { A. A.; Barry, P. J. }\end{array}$ & $\begin{array}{l}\text { Agricultural } \\
\text { and Resource } \\
\text { Economics } \\
\text { Review }\end{array}$ & 2002 \\
\hline 2 & $\begin{array}{c}\text { Social movements beyond the iron } \\
\text { cage: weak ties in territorial } \\
\text { development }\end{array}$ & $\begin{array}{c}\text { Abramovay, R.; } \\
\text { Magalhães, R.; Schroder, } \\
\text { M. }\end{array}$ & $\begin{array}{c}\text { World } \\
\text { Development }\end{array}$ & 2008 \\
\hline 3 & $\begin{array}{c}\text { Horizontal arrangements: strategy } \\
\text { for reducing the asymmetry } \\
\text { information for dairy farmers in } \\
\text { Paraná, Brazil }\end{array}$ & $\begin{array}{l}\text { Brito, M. M.; Bánkuti, F. I.; } \\
\text { Bánkuti, S. M. S.; Ferreira, } \\
\text { M. C. M.; Damasceno, J. } \\
\text { C.; Santos, G. T.; } \\
\text { Zambom, M. A. }\end{array}$ & Ciência Rural & 2015 \\
\hline 4 & $\begin{array}{l}\text { A market controlled by middlemen: } \\
\text { quality standards and } \\
\text { forms of organization of } \\
\text { transactions in a coffee producing } \\
\text { region in Minas Gerais }\end{array}$ & Singulano, M. & $\begin{array}{l}\text { Política \& } \\
\text { Sociedade }\end{array}$ & 2016 \\
\hline 5 & $\begin{array}{l}\text { Theories institutional applied to } \\
\text { agro industrial systems studies in } \\
\text { the context of coffee agribusiness: } \\
\text { a conceptual analysis }\end{array}$ & $\begin{array}{l}\text { Barra, G. M. J.; Ladeira, } \\
\text { M. B. }\end{array}$ & $\begin{array}{l}\text { REGE - } \\
\text { Revista de } \\
\text { Gestão }\end{array}$ & 2016 \\
\hline
\end{tabular}

Source: Prepared by the authors.

All articles selected for the final phase bibliographic review were extracted from the scientific database Portal Periódicos Capes, 60\% of which were published in English and 40\% 
DOI: 10.14807/ijmp.v11i1.1010

of which were published in Portuguese. A comprehensive bibliometric analysis will be carried out in the subtopic 'Overview of the publications,' included in the Results and Discussion section below.

\section{RESULTS AND DISCUSSION}

As explained above, this topic presents main information, conclusions, and comments about the bibliometric data and content of the five publications selected for the bibliographic review. It begins with the subtopic related to the general quantitative data related to the three stages of the SBR, as well as the bibliometric data of the publications considered. Then, in the next subtopic, an analysis of the qualitative information and main contributions of the selected articles is presented.

\subsection{Overview of the publications}

When entering the search strings on the six databases considered for research during processing phase, we noticed a greater return of publications from the database Portal Periódico Capes, which accounted for 98 of the 157 articles identified during the search (after the application of Filters 1 and 2).

Chart 1 presents each database's percentage contribution to the search returns when using the search strings.

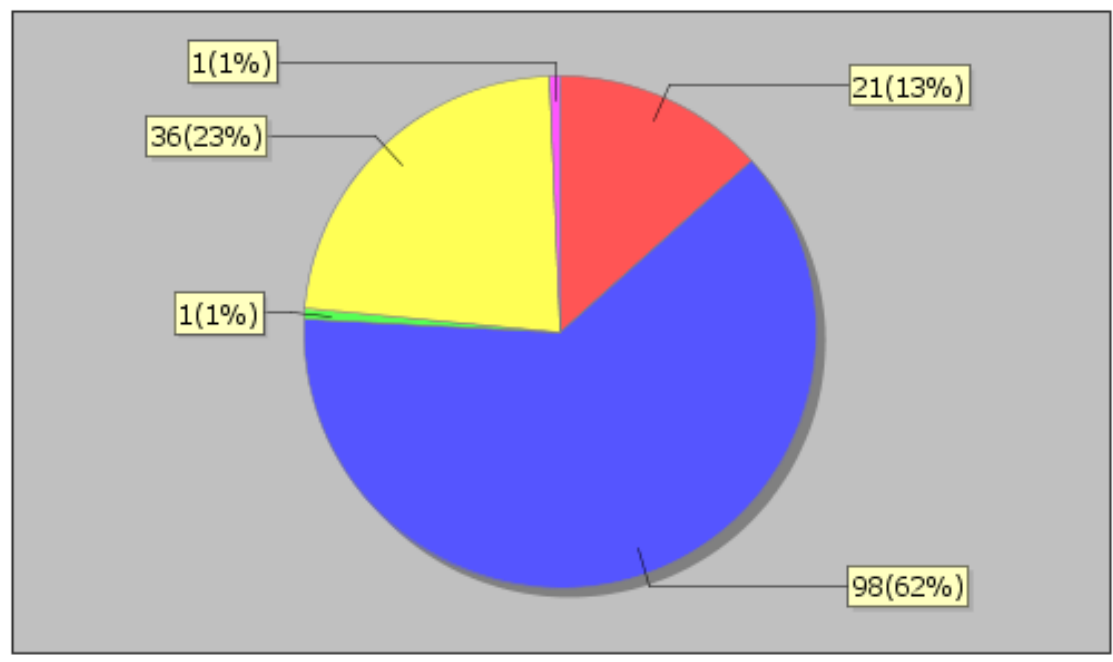

- JSTOR - Portal Periódicos Capes O Scielo O Science Direct O Manually

Chart 1: Contribution of databases to the initial return of the publication search1 Source: Prepared from StArt software.

${ }^{1}$ The graphical view comprises the databases that obtained a return greater than zero after the application of the Boolean search. The indication 'Manually' refers to the manual insertion of a publication coming from the Scielo database, as commented in text. 
As shown in Chart 1, Portal Periódicos Capes provided 62\% of publications and was the most representative of all databases surveyed, followed by Science Direct with 23\%, JSTOR with 13\% and Scielo with $2 \%$. Returned publications from Scielo needed to be manually included in the StArt software due to technical specifications, reflecting the visual results presented in Chart 1.

The initial selection of 157 publications during the processing phase included the application of Filter 3 (reading the titles, abstracts and keywords). After this step, a total of 118 rejected publications, 23 accepted publications and 16 duplicate publications were obtained. The 23 publications accepted to continue in the SBR process were then subjected to the application of Filter 4 (reading the introductions and conclusions) of which $78 \%$ (18 publications) were rejected and 22\% (five publications) were accepted.

Most of the rejected publications discussed networking as applied to supply chains in general. Topics included producers of supplies, product or service reach and final consumers but did not consider networking among members of a single link in the chain, which was the main focus of this review. Other points of disqualification included a superficial approach to the topics and a lack of association with topics considered important to this bibliographical review, such as networked agro-industrial cooperatives and the problem of opportunism.

In general, the main rejection criteria used for publications in this final stage of processing were i) failure to address the interrelationship of all the topics sought, ii) approaching the topics in a superficial way and iii) failing to discuss agribusiness cooperatives. The main acceptance criteria used for the publications were i) discussing agribusiness cooperatives, ii) discussing opportunism, and iii) discussing topics related to the new institutional economy.

As already mentioned, all publications selected after the application of Filter 4 (reading the introduction and conclusion) were also retained after reading the complete publications because all five articles presented the treatment sought in this bibliographic review. The contemporary nature of all the publications considered reaffirms the recent characteristic attributed to the networked economic format as applied to cooperatives in the agro-industrial sector and affirms the need for empirical academic studies of these new hybrid governance formats. 
ISSN: 2236-269X

DOI: 10.14807/ijmp.v11i1.1010

In the analysis of keywords used by the publications considered, we perceived a lack of recurrence of exact terms among the five articles under analysis. The tree diagram of the keywords for the five selected publications is shown in Figure 2.

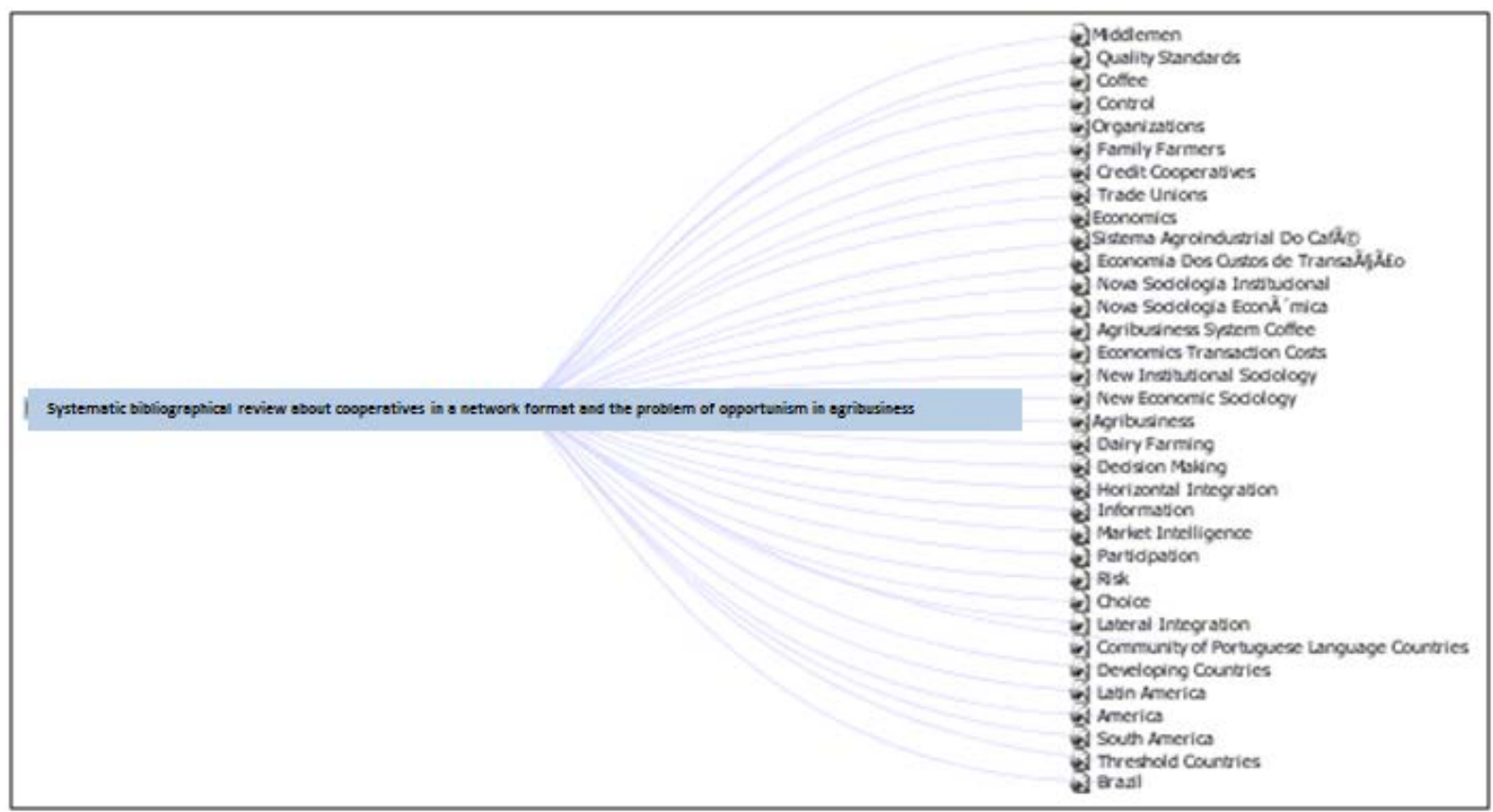

Figure 2: Tree diagram of keywords in the selected publications Source: Prepared by the authors using the StArt software.

Despite the lack of repetition of exact terms among the publication keywords, a constant number of words isolated and used in the composition of the terms as a whole. Examples of this include 'economics,' 'sociology' and 'integration.' These terms represent in a uniform way the main issue addressed by the publications under analysis, in which studies involving new institutional economics tend to also address issues pertaining to sociology and cognition, as well as the integration between agents in the structuring of new economic formats.

\subsection{Content Related to Networked Cooperatives and Opportunism in Agribusiness}

Robinson, Schmid and Barry (2002) frame their contribution to the subject researched in terms of relationships between transacting parties, taking as an example a cooperative of rural fruit producers in which trust based on reputation and respect between cooperatives is presented as important. However, characteristics, such as sympathy and care on the part of agents, go further, positively influencing personal relationships within the cooperative, as well as upstream and downstream relationships in the production chain.

Social capital is characterized as being able to internalize externalities through network relationships in which transaction costs are reduced and the possibility of group improvement is increased, highlighting mutual coordination between agents and the sharing of goals and 
DOI: 10.14807/ijmp.v11i1.1010

experiences in an environment where the exchange of socio-emotional goods and materials, as well as the presence of relationships between the parties, are seen as strategic factors (ROBINSON; SCHMIDT; BARRY, 2002).

Robinson, Schmid and Barry (2002) affirm that trust—understood as a projection of past experiences-emerges as the basis of commercial relations in cases in which contractual incompleteness and a lack of protection against opportunism can be avoided through high levels of coordination between members. The researchers highlight agricultural economists' recognition of the importance of relationships in economic transactions, as well as the statement that in transactions involving relationships of trust and sympathy, risks and opportunistic behaviors are reduced indicating the possibility of exclusion and discrimination against agents that are not part of the same network (ROBINSON; SCHMIDT; BARRY, 2002).

Abramovay and Magalhães (2008) compare the performance and regional repercussions of two cooperatives of rural producers in southern Brazil. Both organizations are characterized by strong foundational ties of identity. A credit cooperative is described by the authors as depending on trust and social mobilization on the part of the producers. This serves as the basis for the operation of their financial activities, such as the granting of loans. The existence of this cooperative derives from the network format and social ties built between members.

The authors argue that cooperation among organized groups contributes to the emergence of an environment of trust favorable to investment, which benefits the development process as a whole, emphasizing the concept of social immersion in economic action, as well as the preference for conducting negotiations in networks based on trust and social proximity, with the purpose of safeguarding against characteristics such as opportunism.

The network format adopted by cooperatives reduces risks and identifies new market options and economic opportunities, facilitating cooperative access to local businesses, political leaders and information in general and contributing to knowledge and development about the economic dynamics of the territory (ABRAMOVAY; MAGALHÃES, 2008). These authors also point out that the leaders of these organizations are immersed in a wide network of social relations and ties that facilitate a strategic vision of the financial situation and social reality.

Brito et al. (2015) conducted an empirical investigation to verify whether the involvement of milk producers in horizontal arrangements-cooperatives-reduces 
DOI: 10.14807/ijmp.v11i1.1010

informational asymmetry. A comparison between two groups of participating and nonparticipating producers was conducted. The authors concluded that these organizations are important to the design of an environment with less asymmetry of information, lower risk and increased access to information by its members when compared with producers who are not part of these arrangements.

New institutional economics and transaction cost economics form the basis of Brito et al.'s (2015) work, which supports the assumption that opportunism caused by information asymmetry is characteristic of economic transactions. Thus, the authors cite the exchange of information between agents of a cooperative as an attitude that strengthens of a productive system in which the risks of opportunistic behavior are reduced by network coordination among small producers to diminish power inequality in transactions downstream and upstream of the production chain.

According to Brito et al. (2015), the bargaining power of agents in economic transactions is often the result of social structures in rural production and is mostly obtained through networking between producers. The authors emphasize the importance of horizontal arrangements among rural producers, attesting that the promotion of information about the economic environment-making their members less susceptible to opportunistic behavior on the part of buyers in transactions and less subject to risks in milk production —is linked to their participation in horizontal arrangements.

Barra and Ladeira (2016) contextualize the institutional environment of the coffee agroindustrial system in Brazil. This system is marked by high transaction costs resulting from the high specificity of the assets, great information asymmetry and the possibility of opportunism. A group of associations and cooperatives called Federação dos Cafeicultores do Cerrado (Coffee Growers Federation) was selected as the main object of analysis, representing a mechanism of coordination built outside the firms.

According to Barra and Ladeira (2016), the reputation of participants in a network generates influence among buyers with respect to the security in the establishment of businesses because the possible use of opportunistic practices by suppliers has the potential to generate disapproval by all members of the network and becomes an informal safeguard mechanism. The authors also affirm that this mechanism reduces transaction costs by reducing the possibility of reprehensible actions in an environment where agents' economic actions are 
DOI: 10.14807/ijmp.v11i1.1010

immersed in social networks that generate social capital, thus reducing opportunistic behaviors and creating trust.

As a result, associations and cooperatives collaborate to coordinate the coffee agroindustrial system because transactions carried out in this chain are executed in an environment of uncertainty and high transaction cost. In their discussion of the performance of agroindustrial production systems, Barra and Ladeira (2016) state that agents demand formal safeguards, such as contracts, and informal safeguards, such as the operation of associations and cooperatives.

Singulano (2016) also analyzes the coffee market in Brazil, specifically the Matas de Minas region. According to the author, this market is characterized by the control of intermediaries in the form of transaction coordinators. The use of the transaction cost economics approach and market sociology to understand the search of the producers for forms of commercial articulation is also highlighted. This is ruled mainly by production cooperatives, which have flourished in the region and represent a form of protection against the globalized market environment.

The coffee marketing chain in Matas de Minas, according to Singulano (2016), has producers on one side and exporters on the other and is a mercantile structure marked by great informational asymmetry that tends to benefit downstream agents to the detriment of producers, contributing to opportunism in transactions between producers and buyers. In this sense, the creation and maintenance of networked cooperatives, constituted by social ties of trust and kinship, become important mechanisms and marketing options for producers in this market (SINGULANO, 2016).

The organization of producers into networks provides an advantage even in the price paid for the product. Even when the market price remuneration is not well received by the producers, the producers themselves are able to influence quality and aggregation of value in the final product—often replacing certification mechanisms—in contractual relationships characterized by greater durability and trust (SINGULANO, 2016). According to Singulano (2016), from the perspective of the producers, the form of coordination that reduces transaction costs and the opportunistic behavior of agents is commercialization by cooperatives, which represents the governance structure expected by this class.

\section{FINAL CONSIDERATIONS}


DOI: $10.14807 /$ ijmp.v11i1.1010

The SBR method facilitates guided and controlled research on the literature of interest from the conception of the objectives of the search to the final selection of articles. The use of the StArt software is highlighted because it made the organization of the publications researched and the optimization and development of the bibliographic review feasible. In this sense, managerial analysis by researchers is generally enhanced by the use of the available tools and graphic design of the searches.

All five articles selected for this bibliographic review attested to the importance of networked agro-industrial cooperatives to reducing opportunism in economic transactions. In particular, the agro-industrial systems of milk, coffee and fruit were taken into account for the composition of the studies. That the analyses were conducted in Brazil also attracted our attention, as four of the five articles discussed Brazilian agro-industrial cooperatives and indicated a possible centralization and analytical reference when considering the theory of hybrid forms of governance in agribusiness.

Finally, the current bibliographic review reinforces the view of the main authors regarding the new institutional economy, the transaction cost theory and hybrid forms of governance. However, the lack of empirical academic studies to enrich and make the researched literature more robust highlights the analytical opportunity for theoretical reinforcement, having as its background a small body of existing literature concerning the current institutional environment of Brazilian agribusiness.

\section{ACKNOWLEDGEMENTS}

The present study is supported by the São Paulo Research Foundation (FAPESP). Grant \#2018/12221-5, São Paulo Research Foundation (FAPESP). The opinions, hypotheses and conclusions or recommendations expressed in this material are the responsibility of the author (s) and do not necessarily reflect the views of FAPESP.

\section{REFERENCES}

ABRAMOVAY, R.; MAGALHÃES, R.; SCHRODER, M. (2008) Social movements beyond the iron cage: weak ties in territorial development. World Development, v. 36, n. 12, p. 29062920.

BARRA, G. M. J.; LADEIRA, M. B. (2016) Teorias institucionais aplicadas aos estudos de sistemas agroindustriais no contexto do agronegócio café: uma análise conceitual. REGE Revista de Gestão, v. 23, p. 159-171. 
BIOLCHINI, J. C. A.; MIAN, P. G.; NATALI, A. C. C.; CONTE, T. U.; TRAVASSOS, G. H. (2007) Scientific research ontology to support systematic review in software engineering. Advanced Engineering Informatics, v.21, n.2, p.133-151.

BRITO, M. M.; BÁNKUTI, F. I.; BÁNKUTI, S. M. S.; FERREIRA, M. C. M.; DAMASCENO, J. C.; SANTOS, G. T.; ZAMBOM, M. A. (2015) Horizontal arrangements: strategy for reducing the asymmetry information for dairy farmers in Paraná, Brazil. Ciência Rural, v. 45, n. 11, p. 2069-2075.

CONFORTO, E. C.; AMARAL, D. C.; SILVA, S. L. (2011) Roteiro para revisão bibliográfica sistemática: aplicação no desenvolvimento de produtos e gerenciamento de projetos. In: CONGRESSO BRASILEIRO DE GESTÃO DE DESENVOLVIMENTO DE PRODUTO, 8, Porto Alegre, Anais... Porto Alegre: CBGDP, 2011.

FUNDECITRUS - Fundo de Defesa da Citricultura. Inventário de árvores e estimativa da safra de laranja do cinturão citrícola de São Paulo e Triângulo/Sudoeste Mineiro 2017/18. Available:

http://www.fundecitrus.com.br/pdf/pes_relatorios/2017_12_05_Invent\%C3\%A1rio_e_Estima tiva_do_Cinturao_Citricola_2017-2018.pdf. Access: 5th March, 2018.

GRANOVETTER, M. (2007) Ação econômica e estrutura social: o problema da imersão. RAE-eletrônica, v. 6, n. 1, p. 1-41.

KALAKI, R. B. (2014) Uma proposta de plano estratégico para o setor citrícola brasileiro. Dissertation (Master in Sciences). Ribeirão Preto: FEARP/USP, Available: http://www.teses.usp.br/teses/disponiveis/96/96132/tde-23072014-150722/pt-br.php. Access: $2^{\text {nd }}$ Oct, 2017.

LEVY, Y.; ELLIS, T. J. (2006) A system approach to conduct an effective literature review in support of information systems research. Informing Science Journal, v.9, p.181-212.

LIN, N. (2001) Social capital: a theory of social structure and action. Cambridge (UK): Cambridge University Press.

NEVES, M. F.; TROMBIN, V. G.; MILAN, P.; LOPES, F. F.; CRESSONI, F.; KALAKI, R. (2010) $O$ retrato da citricultura brasileira. Ribeirão Preto: CitrusBR.

PAULILLO, L. F. (2006) Agroindústria e citricultura no Brasil: diferenças e dominâncias. Rio de Janeiro: E-papers.

ROBISON, L. J.; SCHMID, A. A.; BARRY, P. J. (2012) The role of social capital in the industrialization of the food system. Agricultural and Resource Economics Review, v. 31, n. 1 , p. $15-24$.

SINGULANO, M. (2016) Um mercado controlado por intermediários: padrões de qualidade e formas de coordenação das transações em uma região produtora de café em Minas Gerais. Política \& Sociedade, v. 15, n. 33, p. 11-45. 